
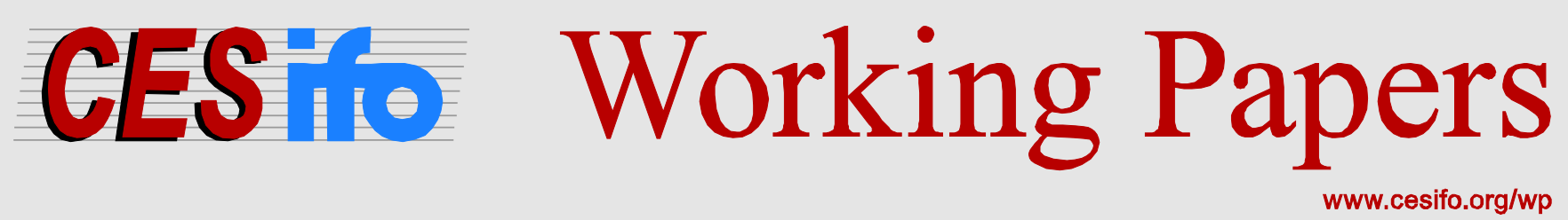

\title{
How Natural is the Natural Rate of Unemployment?
}

\author{
John Komlos
}

CESIFO WORKING PAPER NO. 5004

CATEGORY 4: LABOUR MARKETS

OCTOBER 2014
An electronic version of the paper may be downloaded
- from the SSRN website:
- from the RePEc website:
- from the CESifo website:
WWW.SSRN.com
www.RePEc.org
www.CESifo-group.org/wp

\section{CESifo}




\title{
How Natural is the Natural Rate of Unemployment?
}

\begin{abstract}
The "natural" in the natural rate of unemployment is a misnomer, insofar as unemployment does not occur in nature. The concept is especially misleading because many economists and media commentators inappropriately equate it with "full" employment. As a consequence, endemic un- and underemployment is accepted as an inevitable attribute of the labor market. This is inaccurate inasmuch as the concept assumes that the institutional structure of the labor market is held constant. However, with creative restructuring of that market our aim should be bring the underemployment rate down to $1.2 \%$, the rate that obtained in 1944 and which probably represents the lower bound rate physically attainable. Instead of the prevailing system, the right to work needs to be recognized as a natural right, because the right to life depends upon it. Several ways are proposed to create an inclusive labor market that distributes the available work in a more equitable fashion than the current system.
\end{abstract}

JEL-Code: J480.

Keywords: natural rate of unemployment, labor market, underemployment, right to work, work sharing.

John Komlos

Professor Emeritus

University of Munich / Germany

john.komlos@gmx.de 
The natural rate of unemployment is a concept minted by Milton Friedman to indicate the "level of unemployment which has the property that it is consistent with equilibrium in the structure of real wage rates” (Friedman, 1968, p. 8). Thus, the natural rate is the minimum level of unemployment attainable without an accelerating rate of inflation (Friedman, 1976, p. 458). Its level depends on the characteristics of the labor market and is a function of such factors as "market imperfections, stochastic variability in demands and supplies, the cost of gathering information about job vacancies and labor availabilities, [and] the costs of mobility,...” (Pries 2008). Theoretically, a lower rate of unemployment would be possible temporarily, but it could not be sustained unless at the cost of increasing the rate of inflation, and in the longer run unemployment would return to its "natural” level at a higher inflation rate. In short, it would be futile to use monetary or fiscal policy to try to force the unemployment rate below the natural rate. It would only lead to inflation.

\section{The typical rate of unemployment}

Although the concept may well be valid as stated above, the goal of this note is to argue that the term is nonetheless quite misleading. To be sure, Friedman had the right to name the concept as he pleased; however, contrary to Shakespeare's belief that “a rose by any other name would smell as sweet," in this particular case we think that another name would have been preferable. The use of the word "natural” seems quite disingenuous, because unemployment does not exist normally in nature. Rather, unemployment depends crucially on how the labor market is constituted. In fact, some economists of the $18^{\text {th }}$ century did not even introduce the concept of unemployment into their theories (Sonnenfels, 1777). Hence, the reference to "nature" is actually a misnomer and is merely a subtle rationalization of the inability of the labor market to provide sufficient number of jobs for all in the economy. It would have been more appropriate to call it a "tolerable" rate, the "expected" rate, or even the “typical” rate.

Moreover, the concept conveys the impression that the labor market imperfections that give rise to the level of underemployment deemed natural are etched in stone; it thereby reinforces the impression that the level of unemployment associated with the "natural rate" is actually inevitable and should be considered normal, as it is inherent to the actual functioning of the economy. It is an equilibrium value that we have to tolerate since it would be futile to try to do anything about it. It is just the way the economy works so we have to accommodate ourselves to it. According to the Federal Reserve it has a range between 5.0\% and 6.3\%. It is increased slightly when unemployment is high and decreased when unemployment is low (Federal Reserve Bank of St. Louis, 2014). 
The extent to which the concept is misleading can be illustrated by the tendency of many economists (including Ben Bernanke) to go a step further and often refer to the "natural rate” as "full employment." 1 The media then takes it over and announces outright in a twist of newspeak that 5\% unemployment is "traditional full employment" (Washington Post 2014). That is invidious, because it encourages policy makers to be complacent about the plight of a substantial segment of the labor force and of course, the confusion among the public is complete. Even at 5\% unemployment and an equal amount of underemployment, the cavalier acceptance of the natural rate leads us to do nothing about some 15 million people who fall into those categories and are barely scraping by while the economy is supposedly at “full employment”. That is precisely why Noble laureate William Vickrey referred to the natural rate of unemployment as "one of the most vicious euphemisms ever coined” (1992, p. 341).

\section{Full employment}

It should be clear that the standard policy instruments have a limited ability to reduce unemployment. However, we should think creatively about new labor market institutions that would be effective in reducing unemployment to its lowest ever level of $1.2 \%$ which was obtained in 1944, even though the labor force expanded by $10 \%$ during the war $^{2}$ (Carter et al. 2006). Presumably, that level of unemployment was not related to insufficient demand in the labor market but rather to the physical or mental health of those few remaining unemployed. Of course, that was a time of war but the experience does demonstrate clearly the capacity of the economy to create job opportunities and bring unemployment down to negligible levels depending on aggregate demand. All we have to do is to increase effective demand by declaring a war, not in the conventional sense, of course, and not as Paul Krugman suggested—-tongue in cheek—by declaring an impending alien invasion (Krugman, 2011), but by declaring other kinds of "wars": on inferior school systems, on slums, on decaying infrastructure, on pollution, on global warming, on poverty, or on energy dependence. There is no shortage of such wars given the backlog of desperately needed investments in the economy. These projects could create enough jobs to create full employment for many years to come (Brenner and Brenner-Golomb 2000, Vickrey 1992, Warner, Forstater, and Rosen 2000).

\section{Binary labor market}

The main problem we need to focus on is that the opportunity to work-like wealth and income-is extremely unevenly distributed across the labor force. The problem lies in the way the labor market is organized: the custom is that adjustments in the fluctuations in 
demand for labor generally occur by reducing the number employed so that their labor time falls abruptly from 40 hours to zero. We might call this system a binary labor market: one is either allowed to work 40 hours or one is not allowed to work at all. Would anyone "behind a veil of ignorance” design such a rigid system from scratch, a system with so much uncertainty and volatility-with working times ranging from 0 to 70 hours per week even in normal times (Rawls 1971)? If we were to design the framework without knowing if we would end up among the ranks of the overworked or those of the underemployed, surely, risk-averse designers of a labor market would be too apprehensive about ending up among the underemployed to design the labor market as it functions today (Rawls 1971). It would be much more palatable to have the adjustment occur in the number of hours worked so that instead of dismissing workers, the available work would be divided among those wanting to work. Hence, an institution that distributes work more evenly would be a reasonable solution to this quandary. ${ }^{3}$

\section{Institutional Change in the Labor Market}

Thus, our aim should be to restructure the labor market in such a way that it would generate full employment. Given that the amount of aggregate demand in the economy at any one moment is a given (Y), the amount of work available (L) derived from that is also a given constant. The capital stock is fixed in the short run (K). Hence, the demand for labor

can be approximated as $\left[\mathrm{L}=\left(\frac{Y}{a^{\beta}}\right)^{\frac{1}{1-\beta}}\right]$ and if it falls below full employment (defined here as $\mathrm{L}<1.2 \%$ ) we should reconstitute the institutions of the labor market in such a way as to bring unemployment-including underemployment (U6) down to 1.2\%.

Consider that in the Spring of 2012 the average full-time employee worked 41.9 hours per week and the average part-time employee 20.6 hours per week. The total number of hours worked by full time workers (114.5 million people) and those part-time workers who wanted to work full time (7.9 million people) totaled some 5 billion hours per week. ${ }^{4}$ Dividing the 5 billion hours of work demanded by 135.9 million supplied (the number of people who work or who would like to work full time) one obtains that the full-employment average number of hours worked would have been about 36.5 per week. ${ }^{5}$ Thus, instead of accepting un- and underemployment, one could reduce the number of hours worked for everyone by roughly an hour a day from 8 to 7 hours similarly to what happened when the 10 hour day was reduced to 8 hours. Such a work-sharing system would be a more equitable shock absorber of a decline in the demand for labor than the current system (Baker 2011). 
Other arrangements that would have similar effects include profit sharing wages in which case wages would increase in good times and decrease in recessions so that workers would not have to be fired, keeping the share of total wages in revenue unchanged (Weitzman, 1984). Encouraging cooperatives would also be useful inasmuch as such firms are more likely to adjust pay to fluctuations in demand rather than the number employed (Craig and Pencavel 1992; Pencavel 2002, Rosen, Klein and Young 1986). We should also turn to the only other sufficiently powerful institution that has the ability to provide work: the government (Colander 1981). A government agency could become the employer of last resort similar to the government's role as lender of last resort as provider of a backstop to the financial system (Wray 1997). The new institution--comparable to the Federal Reserve's role in finance--could provide similar stability to the labor market. ${ }^{6}$ It would contribute to an inclusive economy in which no one is deprived of the opportunity to work.

Possibly, the earnings of those previously employed would be reduced as well but the government could offset part of their losses through a subsidy (instead of unemployment payments), and everyone would have more leisure time to enjoy. Such a system would increase the quality of life, because it would reduce the psychological burden of unemployment, increase leisure time, and reduce envy by reducing conspicuous consumption. In addition, it would be a much fairer method of distributing the pain of a decline in the demand for labor than the prevailing binary system.

Instead of thinking of a certain amount of underemployment as natural, we should acknowledge that there is a natural right to life. Insofar as exclusion from work threatens one's very existence (except for the few who are independently wealthy) and given that most of us need to work in order to survive, the right to life implies that we need to be guaranteed the right to work. After all, the UN's Universal Declaration of Human Rights states that, "Everyone has the right to work . . . and to protection against unemployment (UN, 1948).” If the labor market as currently constituted is unable to provide work for everyone then we need to create new institutions that will.

\section{Conclusion}

One should introduce different shock absorbers into the labor market instead of the crude binary system we have today. It would be much more reasonable to distribute the burden of shortfall of available work more equitably than concentrating it among $12 \%$ of the workforce as the labor market does today. If one were designing a labor market from scratch, one would surely design one that lowered the uncertainty associated with being underemployed and shared the pain rather than concentrating it. Working less would also be 
progressive. Progress ought not to be measured only by the amount of income generated but the amount of labor time needed to earn that income should also be considered.

A fairer and more utility generating distribution of work would be important not only to provide the means to making a living but also because underemployment has adverse side effects. It has a destabilizing effect on society both politically and socially. The underemployed generate negative externalities such as an increase in criminality and an increase in stress and anxiety about losing one’s job. Work is important also from a psychological perspective: unemployment is degrading and makes one feel unwanted. The unemployed do not consider themselves useful members of the society and suffer from diminished self-esteem. Their skill depreciates during extended spells of unemployment so that it becomes more difficult for them to find a job. In other words, underemployment increases social misery. For instance, the underemployed are twice as likely to be sad or depressed than the employed and 50\% more likely to be angry (Marlar 2010). They are also more likely to be struggling financially (54\%) in contrast to $38 \%$ of the employed (Manchin 2012).

To liberate ourselves from the commitment to the concept of the natural rate of unemployment is particularly important in light of the "jobless recovery" in wake of the Great Recession. Given the strains of globalization and technological change that diminished considerably the demand for unskilled labor in the developed world, full employment will otherwise continue to elude us forever (Brynjolfsson and McAfee 2012). Currently the rate of underemployment at $12 \%$ amounts to nearly 19 million workers and if each has just one dependent then we have some 38 million people being directly affected by the scarcity of jobs (Bureau of Labor Statistics, 2014). That is hardly a negligible matter especially since endemic underemployment is likely to be with us for the foreseeable future unless we begin to think creatively about alternative approaches to providing jobs for everyone (Summers 2014). ${ }^{7}$ Thus, the concept of the natural rate of unemployment "is an idea that is past its sellby-date" (Farmer 2013). We ought to think seriously about restructuring the labor market to meet the needs of the $21^{\text {st }}$ century economy and not rely on the current system to allocate work equitably. 


\section{References}

Baker, Dean. 2011. Work Sharing: The Quick Route Back to Full Employment (Washington, D.C.: Center for Economic and Policy Research), available at http://www.cepr.net/documents/publications/work-sharing-2011-06.pdf (accessed May 21, 2012).

Brenner, Yehojachin Simon and Brenner-Golomb, Nancy. 2000. A Theory of Full Employment, $2^{\text {nd }}$ ed (New Brunswick, NJ: Transaction Publishers).

Brynjolfsson, Erik and McAfee, Andrew. 2012. Race Against the Machine: How the Digital Revolution is Accelerating Innovation, Driving Productivity, and Irreversibly Transforming Employment and the Economy, Digital Frontier Press.

Bureau of Labor Statistics, Table A-15. Alternative measures of labor underutilization. http://www.bls.gov/news.release/empsit.t15.htm accessed June 16, 2014.

Carter, Susan B., Gartner, Scott Sigmund, Haines, Michael, R. Olmstead, Alan L. Sutch, Richard and Gavin Wright, 2006. Historical Statistics of the United States. Millennial Edition online. Cambridge: Cambridge University Press, Table Ba470-477 - Labor force, employment, and unemployment: 1890-1990.

Colander, David. 1981. “A Guaranteed Jobs Proposal,” in David Colander (ed.), Solutions to Unemployment (New York: Harcourt Brace Jovanovich, Inc.), pp. 204-208.

Craig, Ben and Pencavel, John. 1992. "The Behavior of Worker Cooperatives: The Plywood Companies of the Pacific Northwest,” American Economic Review 82, 5: 10831105.

Du, Zaichao, Yin, Hua, and Zhang, Lin. 2013. “The macroeconomic effects of the 35h workweek regulation in France,” B.E. Journal of Macroeconomics 13(1): 881-901.

Farmer, Roger E.A. 2014. “The Natural Rate Hypothesis: An idea past its sell-bydate,” Unpublished manuscript, UCLA. http://www.rogerfarmer.com/NewWeb/PdfFiles/The\%20NRH\%20\%20Farmer\%20R11\%20WP\%20version.pdf Accessed August 5, 2014.

Federal Reserve Bank of St. Louis. Economic Research. http://research.stlouisfed.org/fred2/series/NROU accessed June 16, 2014.

Friedman, M. 1968. The role of monetary policy. American Economic Review 58, 1 17.

Friedman, M. 1977. “Nobel Lecture: Inflation and Unemployment,” Journal of Political Economy 85, 3, 451-472. 
Krugman, Paul. 2010. “Kurzarbeit,” The New York Times, September 2, 2010, http://krugman.blogs.nytimes.com/2010/09/02/kurzarbeit/ (accessed May 20, 2014).

Krugman, Paul, 2011. “Coalmines and Aliens,” The New York Times, August 24, 2011. http://krugman.blogs.nytimes.com/2011/08/24/coalmines-and-aliens/ accessed June 16, 2014.

Manchin, Anna. 2012. "Depression Hits Jobless in UK, U.S. More than in Germany,” Gallup, November 21, http://www.gallup.com/poll/158879/depression-hits-joblessgermany.aspx (accessed July 21, 2014).

Marlar, Jenny. 2010. “The Emotional Cost of Underemployment,” Gallup, March 9, http://www.gallup.com/poll/126518/Emotional-Cost-Underemployment.aspx accessed May 6, 2014.

Pencavel, John. 2002. Worker Participation. Lessons from the Worker Co-ops of the Pacific Northwest ( New York: Russell Sage Foundation).

Pries, Michael J. "natural rate of unemployment." The New Palgrave Dictionary of Economics. Second Edition. Eds. Steven N. Durlauf and Lawrence E. Blume. Palgrave Macmillan, 2008. The New Palgrave Dictionary of Economics Online. Palgrave Macmillan. 12 June 2014 http://www.dictionaryofeconomics.com/article?id=pde2008_N000024

Rawls, John. 1971. A Theory of Justice (Cambridge, MA: Harvard University Press).

Rosen, Corey, M., Klein, Katherine J. and Young, Karen M. 1986. Employee Ownership in America. The Equity Solution. Lexington, MA: Lexington Books.

Sonnenfels, Josef von. 1777. Grundsätze der Polizey, Handlung und Finanz, Part 1, Vienna.

Summers, Larry. 2014. “Secular stagnation? The Future Challenge for Economic Policy,” http://ineteconomics.org/institute-blog/secular-stagnation-future-challengeeconomic-policy accessed September 11, 2014.

United Nations, 1948. "The Universal Declaration of Human Rights,” http://www.un.org/en/documents/udhr/index.shtml (accessed June 13, 2014).

Vickrey, William. 1992. “Chock-Full Employment without Increased Inflation,” American Economic Review, 82, 2: 341-45.

Warner, Aaron, W., Forstater, Mathew, W., and Rosen, Sumner M. 2000. Commitment to Full Employment. The Economics and Social Policy of William S. Vickrey (New York: M.E. Sharpe). 
Washington Post, “A brief history of U.S. unemployment. http://www.washingtonpost.com/wp-srv/special/business/us-unemployment-rate-history/ Accessed June 13, 2014.

Weitzman, Martin. 1984. The Share Economy Cambridge: Harvard University Press. Wray, L. Randall. 1997. “Government as Employer of Last Resort: Full Employment Without Inflation,” Levy Economics Institute Working Paper No. 213.

\section{Endnotes}

1 "Ben Bernanke Was Wrong," YouTube video, posted by “Marcus C. Macellus,” July 22, 2009. https://www.youtube.com/watch?v=9QpD64GUoXw accessed August 30, 2014. 2 Unemployment was also as low in 1918.

${ }^{3}$ Some tentative steps in this direction were taken in the 2012 “Job Creation Act." Such a program works in Germany where total employment has not decreased at all during the Meltdown (Krugman, 2012). The reduction of the workweek in France from 39 to 35 hrs in large firms in the year 2000 is estimated to have reduced unemployment rate by $1.6 \%$ by 2002 (Du, Yin and Zhang 2013).

${ }^{4}$ There are an additional 0.5 billion hours worked per week by part time workers who do not want to work full time and multiple job holders combined. They are not included in this exercise, as they would not have to be provided a full time job.

${ }^{5}$ Full employment $=$ full time workers + unemployed + part time who want to work full time + discouraged workers.

${ }^{6}$ Moreover, in the age of the information technology (IT) revolution it ought to be possible to match vacancies to willing workers instantaneously, thereby eliminating frictional unemployment. The government could subsidize the cost of relocation and retraining. It is not the case that we have to accept any unemployment as natural.

7 “High involuntary unemployment can persist as an equilibrium of a market economy” (Farmer 2013). 